\title{
Glecaprevir/Pibrentasvir Treatment in a Patient with Hemophilia and Mixed Genotype Hepatitis C Infection
}

\section{Mikst Tip Hepatit C Genotipine Sahip Hemofili Hastasının Glecaprevir + Pibrentasvir ile Tedavisi}

\author{
๑ Ömer Karaşahin ${ }^{1}$, ๑ Emine Füsun Karaşahin² \\ 1 University of Health Sciences Turkey, Erzurum Region Training and Research Hospital, Clinic of Infectious Diseases and Clinical Microbiology, Erzurum, \\ Turkey \\ 2Erzurum Provincial Health Directorate, Presidency of Public Health Services, Erzurum, Turkey
}

\begin{abstract}
Patients who require frequent blood product transfusions, such as patients with hemophilia, are at risk of contracting hepatitis $\mathrm{C}$ virus (HCV). The prevalence of mixed HCV genotype infection is higher in this patient group. The patient presented here was a 22-yearold Afghan citizen who had received blood product transfusions since birth due to hemophilia A. He was found to have HCV infection during follow-up in the hematology clinic three years ago, and HCV genotypes $1 \mathrm{~b}, 3$, and 4 were detected. Treatment with glecaprevir/pibrentasvir was administered for 8 weeks. The patient reported no side-effects other than headache that resolved when treatment was discontinued. Transaminase values improved from pre-treatment level and were within normal limits at the end of the treatment. The patient showed sustained virologic response at 24 weeks. Pangenotypic direct-acting antivirals, which have just been included in the reimbursement scope in our country, have eliminated the difficulty in choosing drugs in this indication. Single drug administration has led to more successful patient outcomes by increasing treatment compliance.

Keywords: Antiviral drugs, hemophilia A, hepatitis C virus
\end{abstract}

\section{ÖZ}

Hemofili hastalığı gibi sık kan ürünü transfüzyonu gerektiren hastalıklara sahip hastalar hepatit $\mathrm{C}$ bulaşı açısından risk altındadır. Bu grup hastalarda mikst hepatit $\mathrm{C}$ virüs $(\mathrm{HCV})$ genotip prevalansı daha yüksektir. Olgumuz, 22 yaşında Afganistan uyruklu ve hemofili A hastalı̆ı nedeni ile doğumdan itibaren kan ürünü transfüzyonu yapılan bir hastadır. Üç yıl önce hematoloji kliniğinin takipleri sırasında HCV enfeksiyonu saptand. HCV genotip $1 b, 3$ ve 4 tespit edildi. Glekaprevir/pibrentasvir tedavisi 8 hafta verildi. Baş ağrısı dışında bir yan etki gözlenmedi ve tedavinin sonlanması ile yakınması geriledi. Tedavi başlangıına göre tedavi sonunda transaminaz değerleri normal sınırlarda izlendi. Yirmi dördüncü hafta kalıcı virolojik yanıtı sağlanan hasta başarılı bir şekilde tedavi edildi. Ülkemizde geri ödeme kapsamına henüz giren pangenotipik direkt etkili antiviraller, bu endikasyonda ilaç seçim güçlüğünü ortadan kaldırmıştır. Tek ilaç uygulaması, tedaviye uyumunu artırarak daha başarıı hasta sonuçlarına yol açmıştır.

Anahtar Kelimeler: Antiviral ilaçlar, hemofili A, hepatit C virüsü

Karaşahin 0̈, Karaşahin EF. Glecaprevir/Pibrentasvir Treatment in a Patient with Hemophilia and Mixed Genotype Hepatitis C Infection. Viral Hepat J. 2021;27:159-161.

\section{Introduction}

Most hemophilia patients who received blood products prior to the implementation of virus inactivation procedures were infected with hepatitis $\mathrm{C}$ virus (HCV) (1). Hemophilia $A$, the most common hemophilia, is caused by an abnormal factor VIII gene located on the $X$ chromosome and affects 1 in 5,000 males (2). According to the literature, hemophilia patients have significantly higher rates of
anti-HCV positivity (70-90\%) compared to the normal population $(3,4)$. The prevalence of HCV was also reported to increase in parallel with the need for factor concentration, which increases with hemophilia severity (2). Moreover, it has been shown that deaths from chronic liver disease and liver cancer due to viral hepatitis are more common in hemophilia patients than in the general population (1). 
In the management of $\mathrm{HCV}$, pegylated interferon and ribavirin combination therapy has been associated with a high discontinuation rate due to the longer treatment duration and adverse effects (5). The use of direct-acting antivirals (DAAs) has substantially increased treatment success. The approval of DAAs with pangenotypic efficacy has also simplified antiviral treatment selection for patients with mixed HCV genotypes (6). Here we present a patient with hemophilia and mixed genotype $\mathrm{HCV}$ infection who was successfully treated with pangenotypic glecaprevir and pibrentasvir (GLE and PIB) therapy.

\section{Case Report}

A 22-year-old Afghan man had a history of repeated transfusions due to hemophilia A. During follow-up in the hematology department for hemarthrosis, he was referred to the infectious diseases outpatient clinic when he was found to be anti-HCV positive. At initial presentation, he tested positive for anti-HCV, anti-HBs, and anti-HAV immunoglobulin G (lgG) and negative for anti-human immunodeficiency virus (anti-HIV), hepatitis B surface antigen, and anti-HBc IgG. HCV genotypes $1 \mathrm{~b}, 3$, and 4 were detected and HCV-RNA level was 19,212.349 IU/mL. Other initial laboratory values were alpha-fetoprotein $2.94(0-8.1) \mathrm{ng} / \mathrm{mL}$, alanine aminotransferase (ALT) 155 (0-55) U/L, aspartate aminotransferase (AST) 66 (5-34) U/L, albumin 46.20 (35-50) g/L, creatinine (Cre) $0.96(0.72-1.25) \mathrm{mg} / \mathrm{dL}$, hemoglobin $(\mathrm{Hb}) 16.8(14.1-17.8) \mathrm{g} / \mathrm{dL}$, platelet count (PLT) 221 (152-383) x10\%/L, white blood cell count (WBC) 5.08 (3.91-10.90) $\times 10^{9} / \mathrm{L}$. On abdominal ultrasound, the liver was of normal size with smooth contours and homogeneous echogenicity, and the intrahepatic bile ducts and vascular structures appeared normal. There was no sign of a space-occupying lesion in the parenchyma. Sinus rhythm was normal on electrocardiography.

The patient was HCV treatment naive, non-cirrhotic, and had an AST to platelet ratio index of 0.782 . Treatment with pangenotypic GLE/PIB was initiated 3 times a day. In follow-up examination at week 4 of treatment, the patient's only complaint was headache which was started at the first week of the treatment. However, it was not severe enough to warrant discontinuation, and treatment was continued for a total of 8 weeks. After completing treatment, he tested negative for HCV-RNA at 12-week follow-up. At 24-week follow-up, he was still negative for HCV-RNA and his laboratory values were ALT: $23 \mathrm{U} / \mathrm{L}, \mathrm{AST}: 22 \mathrm{U} / \mathrm{L}$, albumin $48.62 \mathrm{~g} / \mathrm{L}$, Cre: $0.80 \mathrm{mg} / \mathrm{dL}, \mathrm{Hb}: 17.2 \mathrm{~g} / \mathrm{dL}, \mathrm{PLT}: 235 \times 10^{9} / \mathrm{L}$, and WBC: $7.20 \times 10^{9} / \mathrm{L}$. Based on his sustained virologic response (SVR) and transaminase values within normal limits, treatment was considered successful.

\section{Discussion}

In this report, we present a 22-year-old hemophilia patient with mixed genotype HCV infection who achieved SVR after treatment with GLE/PIB. Although there is some geographical variability, the prevalence of mixed genotype HCV infection in the general patient population is approximately $2 \%$ to $7 \%$ (7). Mixed genotype HCV infection is more common in populations with high risk of $\mathrm{HCV}$ exposure and may be the result of co-infection or superinfection $(8,9)$. The frequency of mixed genotype HCV infection is higher in hemophilia patients compared to the general population $(10,11)$. In addition, as hemophilia patients can be exposed to several thousand donors with a single factor infusion, their HCV genotypes generally reflect the dominant genotype of the donor population (2). Genotypes 1 and 3 are predominant in the general population of Afghanistan (12). Our patient was an Afghan immigrant with a history of repeated factor transfusion from birth and was found to have mixed HCV genotype (1b, 3, and 4).

There is insufficient data on DAA therapy for mixed genotype $\mathrm{HCV}$ infection. In a real-life study conducted in Taiwan, $2.2 \%$ of HCV patients who received ledipasvir/sofosbuvir (LDV/SOF) and GLE/PIB between 2017 and 2019 had mixed infections with double or triple combinations of the genotypes $1 \mathrm{a}, 1 \mathrm{~b}, 2,3$, and 6. Rates of SVR at 12 weeks (SVR12) were found to be $96.6 \%$ with LDV/SOF therapy and $100 \%$ with GLE/PIB therapy, and both treatments were associated with high SVR12 rates in patients with mixed genotype HCV infections (13). In another study evaluating the real-life results of GLE/PIB therapy, the frequency of mixed genotype infection was $1.4 \%$ and all of those patients achieved SVR (14). Similarly, in the present case, our non-cirrhotic, treatmentnaive patient with mixed HCV genotype demonstrated SVR at 24 week after 8 weeks of pangenotypic GLE/PIB.

In a study reported from our country, 21 patients, 15 of whom were intravenous drug users, were shown to be infected with two different HCV genotypes. DAA treatment was applied to the patients. Virological response was achieved in all of those evaluated at the end of treatment. It has been emphasized that DAA treatment can be successful in breaking the chain of transmission in the community as well as the treatment of the infected person (15).

\section{Conclusion}

Patients with a history of blood product transfusion have a clear risk for mixed genotype HCV infection. This case demonstrates that patients with high risk of mixed genotype HCV infection can be successfully treated without genotyping using pangenotypic DAAs, which were recently included in the reimbursement coverage in our country.

\section{Ethics}

Informed Consent: Written informed consent was obtained from the patient included in the study and our study was conducted in accordance with the Declaration of Helsinki Principles.

Peer-review: Externally peer-reviewed.

\section{Authorship Contributions}

Surgical and Medical Practices: Ö.K., Concept: Ö.K., Design: Ö.K., Data Collection or Processing: Ö.K., Analysis or Interpretation: E.F.K., Ö.K., Literature Search: E.F.K., Ö.K., Writing: E.FK., Ö.K.

Conflict of Interest: No conflict of interest was declared by the authors.

Financial Disclosure: The authors declared that this study received no financial support.

\section{References}

1. Darby SC, Ewart DW, Giangrande PL, Spooner RJ, Rizza CR, Dusheiko GM, Lee CA, Ludlam CA, Preston FE. Mortality from liver cancer and liver disease in haemophilic men and boys in UK given blood products contaminated with hepatitis C. Lancet. 1997;350:1425-1431. 
2. Fried MW. Management of hepatitis $C$ in the hemophilia patient Am J Med. 1999;107:85S-89.

3. Kumar A, Kulkarni R, Murray DL, Gera R, Scott-Emuakpor AB, Bosma K, Penner JA. Serologic markers of viral hepatitis A, B, C, and D in patients with hemophilia. J Med Virol. 1993;41:205-209.

4. Eyster ME, Diamondstone LS, Lien J-M, Ehmann WC, Quan S, Goedert JJ. Natural history of hepatitis C virus infection in multitransfused hemophiliacs: effect of coinfection with human immunodeficiency virus. The Multicenter Hemophilia Cohort Study. J Acquir Immune Defic Syndr. 1993;6:602-610.

5. Yang Z, Zhuang L, Yang L, Liu C, Lu Y, Xu Q, Chen X, Chen L. Efficacy and safety of peginterferon plus ribavirin for patients aged $\geq$ 65 years with chronic hepatitis C: a systematic review and metaanalysis. Clin Res Hepatol Gastroenterol. 2014;38:440-50.

6. D’Ambrosio R, Pasulo L, Puoti M, Vinci M, Schiavini M, Lazzaroni S, Soria A, Gatti F, Menzaghi B, Aghemo A, Capelli F, Rumi MG, Morini L, Giorgini A, Pigozzi MG, Rossini A, Maggiolo F, Pan A, Memoli M, Spinelli O, Del Poggio P, Saladino V, Spinetti A, De Bona A, Capretti A, Uberti-Foppa C, Bonfanti P, Terreni N, Menozzi F, Colombo AE, Giglio O, Centenaro R, Borghi M, Baiguera C, Picciotto V, Landonio S, Gori A, Magnani C, Noventa F, Paolucci S, Lampertico P, Fagiuoli S; NAVIGATORE-Lombardia Study Group. Real-world effectiveness and safety of glecaprevir/pibrentasvir in 723 patients with chronic hepatitis C. J Hepatol. 2019;70:379-387.

7. Suntur BM, Ünal N, Kaya H, Kara B, Eker HBȘ. Direct-acting antiviral therapy for mixed genotype chronic hepatitis C infection. Viral Hepat J. 2019;25:55-58.

8. Walker MR, Li H, Teutsch S, Betz-Stablein B, Luciani F, Lloyd AR, Bull RA. Incident hepatitis c virus genotype distribution and multiple infection in australian prisons. J Clin Microbiol. 2016;54:1855-1861.
9. Cunningham EB, Applegate TL, Lloyd AR, Dore GJ, Grebely J. Mixed $\mathrm{HCV}$ infection and reinfection in people who inject drugs-impact on therapy. Nat Rev Gastroenterol Hepatol. 2015;12:218-230.

10. Buckton AJ, Ngui SL, Arnold C, Boast K, Kovacs J, Klapper PE, Patel B, Ibrahim I, Rangarajan S, Ramsay ME, Teo CG. Multitypic hepatitis $C$ virus infection identified by real-time nucleotide sequencing of minority genotypes. J Clin Microbiol. 2006;44:2779-2784.

11. Preston FE, Jarvis LM, Makris M, Philp L, Underwood JC, Ludlam CA, Simmonds P. Heterogeneity of hepatitis $C$ virus genotypes in hemophilia: relationship with chronic liver disease. 1995;85:12591262.

12. Husseini AA, Saeed KMI, Yurdcu E, Bozdayı AM. Molecular epidemiology of hepatitis $B$ virus, hepatitis $C$ virus, and hepatitis $\mathrm{D}$ virus in general population of Afghanistan. Turk J Gastroenterol. 2020;31:658-666.

13. Chiu WN, Hung CH, Lu SN, Chen MY, Tung SY, Wei KL, Lu CK, Chen $\mathrm{CH}, \mathrm{Hu} \mathrm{TH}, \mathrm{Hu} \mathrm{JH}$, Chen WM, Chang TS. Real world effectiveness of glecaprevir/pibrentasvir and ledipasvir/sofosbuvir for mixed genotype hepatitis $\mathrm{C}$ infection: A multicenter pooled analysis in Taiwan. J Viral Hepat. 2020;27:866-872.

14. Liu CH, Liu CJ, Hung CC, Hsieh SM, Su TH, Sun HY, Tseng TC, Chen PJ, Chen DS, Kao JH. Glecaprevir/pibrentasvir for patients with chronic hepatitis C virus infection: Real world effectiveness and safety in Taiwan. Liver Int. 2020;40:758-768.

15. Suntur BM, Ünal N, Kaya H, Kara B, Eker HBŞ. Direct-acting antiviral therapy for mixed genotype chronic hepatitis $\mathrm{C}$ infection. Viral Hepat J. 2019;25:55-58. 